\title{
EFFECTIVENESS OF THREE APPROACHES TO COLLEGE HEALTH INSTRUCTION*
}

\author{
C. Harold Veenker and A.H. Ismail \\ Purdue University
}

\section{Abstract}

The investigation was conducted to determine the relative effectiveness of three different approaches to health instruction at the college level. Each of three groups of students was taught by one instructional approach: problem solving, lecture, or discussion. Analysis of initial and final measurements of health knowledge, health attitudes, and health interests through the covariance technique and $t$ tests indicated that all three approaches were equally effective in the achievement of instructional outcomes.

Educators are perennially confronted with the problem of selecting an instructional approach most favorable to the achievement of certain educational objectives, and educational theorists have produced considerable writing on the subject. The merits of a particular approach are convincingly presented, but may be in conflict with equally convincing arguments cited to recommend a different approach. Proponents of the various techniques frequently bast their beliefs upon subjective, personal observations or the conclusions of other teachers with similar experiences rather than upon objective evidence which indicates the relative effectiveness of the various approaches at specific educational levels. The classroom teacher must either accept this type of empirical judgement or seek objective information on the best approach to use in a given situation.

The literature pertaining to the methodology of health instruction increasingly appears to emphasize the desirability of using the problem solving and/or discussion approaches. Proponents of these approaches state that they not only effectively increase health knowledge but also have the added advantage of favorably influencing attitudinal development and health interests. Yet it appears that for the most part, college health instruction continues to follow the traditional lecture approach. Advocates of the lecture method point out that the major objective in college health instruction is to increase health knowledge and therefore the teacher-centered lecture approach is most favorable for attaining the particular objectives at this educational level.

Many of the discussions describing attempts to resolve these conflicting viewpoints present observations made in essentially uncontrolled situations $(1,10,12)$ and/or in the investigation of a single approach $(2,4,5)$ or from generalization drawn from related studies $(1,8,11,13)$. Such work is recognized as a valuable contribution to improve health instruction at all educational levels, but a comparative analysis of the results of certain recommended approaches applied under controlled conditions would yield evidence as to their relative effectiveness.

* The Research Quarterly, 1962,33: 129-135. 
Health educators have generally recognized the urgent need for classroom research which will yield valid evidence basic to the improvement of health instruction. This study should help to illustrate classroom research which can be conducted by health instructors, thus contributing toward needed research methodology in health education.

The purpose of this program, therefore, was to investigate the relative effectiveness of three selected approaches - problem-solving, discussion, and lecture - to the health instruction of undergraduate college students in order to identify an approach, or approaches, which may be favored by the analysis of the data. Each approach was investigated as to its effect upon health knowledge, health attitudes, and health interests held by college students.

\section{DEFINITION OF TERMS}

Problem solving approach is a complex of many learning functions arranged in a continuum through which students identify health problems and seek a tenable solution by gathering appropriate information, hypothesizing possible solutions, testing hypotheses, and interpreting the results in terms of

health behavior. Content, activities, and learning experiences are determined by student-indicated health problems within the framework of designated health learning areas.

Discussion approach is essentially a group process, primarily the interchange among students of questions and answers, informative comments and viewpoints, and interpretations of information concerning health matters, with the instructor acting largely as moderator. The instructor may define the area of discussion, supply information when asked for it, illustrate points already made, or pose leading questions. In essence, the instructor promotes an orderly sequence or discussion by relating activities and content to the central topic. Included in this approach are such specific techniques as group discussion, buzz sessions, panels and symposiums.

Lecture approach is essentially the teacher-center presentation of subject matter through the traditional textbook-lecture technique, the more or less continuous oral presentation of a prescribed body of health information, including assigned oral reports by students closely related to the sequence of informational content as read by students in a basic textbook.

\section{METHODS AND PROCEDURES}

The subjects of the investigation were 104 students enrolled in three sections of the regularly scheduled undergraduate course in Personal and Community Hygiene at Purdue University. The majority of the subjects were students with major or minor programs in health and physical education; other subjects were enrolled in major programs in other curricular areas such as elementary education, biology, and science. The students were randomly assigned to each of the three sections of the class through the mechanical procedure used by the Office of the Registrar. Class sections were scheduled to meet at 8:00 a.m., 11:00 a.m., and 3:00 p.m. on each Sunday, Wednesday and Friday during the first semester of the 1950-60 academic years. The same instructor taught all three sections throughout the study. Each section received a total of 48 50-minute periods of instruction.

The Kilander Health Knowledge Test (9), Byrd Health Attitude Scale (3), and Whitely Health Interest Checklist (14) were administered to obtain initial and final measurements. The primary function 
of the Kilander test is to measure the extent of the college student's knowledge and understanding in major content areas pertaining to health. The Byrd Health Attitude Scale is designed to measure the intensity of the health attitudes of the group or of the individual for the purpose of discovering attitudinal differences. Scores ranging above 400 points indicate desirable attitudes which can be expected to affect health behavior. The Whitely Health Interest Checklist provides a means of measuring the degree of student interest in 134 health topics categorized in 14 areas of health information.

The problem solving, lecture and discussion approaches to instruction were assigned to Group I, Group II and Group III, respectively, by random number drawing. Preliminary class orientation, testing procedures, and access to available informational sources were the same for all sections.

Measurements of health knowledge, health attitudes, and health interests were obtained at the beginning and at the end of the semester. All instruments were administered to each section by the same instructor according to standard instructions for each instrument. To reduce the effect of bias in the stated health interests of students, a code numbering system was used with the Health Interest Checklist so that the individual subject's check list could be identified only after the grading period was completed.

Following initial measurements, class instruction was conducted in accordance with the recommended techniques for each approach. Although a required basic text (6) was sued with all sections specific course content was not rigidly structured to be the same in all sections or to follow the textbook sequence of subject matter. The course was organized to include three general categories of health information; beginning life, health care in routine living, and health protection. In each category, the various health topics organized for study and the actual emphasis on specific content were determined primarily by the types of learning experiences involved in each approach.

The analysis of covariance was adopted for the purpose of identifying the approach or approaches which might yield significance in outcomes achieved. Through this process the final scores were adjusted on the initial scores for each specific kind of outcome, health knowledge, Health attitudes, and health interests. For each type of outcome, the degree of achievement between initial and final scores was subjected to the simple $t$ test. The 5 percent level of confidence was selected as the significance level for all tests.

Certain conditions inherent in the experimental situation were recognized as having possible limiting effects upon the research procedures used and upon the interpretation of findings. Limiting factors included the randomness of experimental subjects in sections, which is dependent upon the mechanical procedure of assigning students to class sections used at this university; the degree to which the instructor was able to implement the three instructional approaches with equal skill; the degree of validity of the instruments available to measure the various instructional outcomes; and the degree to which inflexibility of "set" toward problem solving, discussion, or lecture is present among the students in each instructional group and its effect (interference) upon the learning processes involved. 


\section{ANALYSIS OF THE DATA}

To accomplish the purpose of the study, 12 null hypotheses were tested. Three hypotheses wee concerned with the effect of the three selected approaches upon health, health attitudes, and health interests. Nine were devoted to the determination of the amount of achievement in health knowledge, attitudes, and interests under each of the three approaches.

The null hypotheses pertaining to the three selected approaches in terms of health knowledge, health attitudes, and health interests wee held tenable, since the F values obtained were too small for significance (Tables 1, 2, 3). The problem solving lecture, and discussion approaches wee found to be of equal effectiveness in the achievement of instructional outcomes.

The difference between the initial and the final mean knowledge scores was found to be significant under each approach (Table 4). The null hypotheses were rejected beyond the 5 percent level of confidence.

TABLE I

THE ANALYSIS OF COVARIANCE OF THE HEALTH KNOWLEDGE SCORES OF THREE GROUPS OF SUBJECTS

\begin{tabular}{lcrcc}
\hline Source of Variation & $\begin{array}{c}\text { Adjusted Sum } \\
\text { of Squares }\end{array}$ & df & $\begin{array}{l}\text { Adjusted } \\
\text { Variance }\end{array}$ & F \\
\hline Between Groups & 81.24 & 2 & 40.62 & $1.671^{*}$ \\
Within Groups & 2260.68 & 93 & 24.31 & \\
$\quad$ Total & 2341.92 & 95 & & \\
\hline
\end{tabular}

significant at the 5 percent level.

TABLE II

THE ANALYSIS OF COVARIANCE OF THE HEALTH ATTITUDE SCORES OF THREE GROUPS OF SUBJECTS

\begin{tabular}{lcrrr} 
Source of Variation & $\begin{array}{c}\text { Adjusted Sum } \\
\text { of Squares }\end{array}$ & df & $\begin{array}{c}\text { Adjusted } \\
\text { Variance }\end{array}$ & F \\
\hline Between Groups & 19.70 & 2 & 9.85 & $0.019^{*}$ \\
Within Groups & 4102.10 & 93 & 527.98 & \\
$\quad$ Total & 4121.80 & 95 & 527.98 & \\
\end{tabular}

*Not significant at the 5 percent level.

*Not significant at the 5 percent level. 
TABLE III

THE ANALYSIS OF COVARIANCE OF THE HEALTH INTEREST SCORES OF THREE GROUPS OF SUBJECTS

\begin{tabular}{lcccc}
\hline Source of Variation & $\begin{array}{c}\text { Adjusted Sum } \\
\text { of Squares }\end{array}$ & df & $\begin{array}{c}\text { Adjusted } \\
\text { Variance }\end{array}$ & F \\
\hline Between Groups & 160.10 & 2 & 80.05 & $0.565^{*}$ \\
Within Groups & 12329.12 & 87 & 141.71 & \\
$\quad$ Total & 12489.22 & 89 & & \\
\hline
\end{tabular}

Not significant at the 5 percent level.

TABLE IV

APPLICATION OF THE t-TEST TO INITIAL AND FINAL HEALTH KNOWLEDGE SCORES MADE BY THREE GROUPS

\begin{tabular}{lcccccccc}
\hline & \multicolumn{4}{c}{$\begin{array}{c}\text { Initial } \\
\text { Group Approach }\end{array}$} & $\begin{array}{l}\text { Mean } \\
\text { Mean }\end{array}$ & $\begin{array}{c}\text { Differ- Error of } \\
\text { ence } \\
\text { Difference }\end{array}$ & df & \multicolumn{3}{c}{$\begin{array}{c}\text { Obtained } \\
\mathrm{t}\end{array}$} & $\begin{array}{c}\text { Value } \\
\text { of Sig- } \\
\text { nificance }\end{array}$ & results \\
\hline Problems & 68.03 & 78.74 & 10.71 & 2.45 & 60 & 4.351 & 2.000 & $\mathrm{~S}$ \\
I Lecture & 67.05 & 75.41 & 8.36 & 1.96 & 76 & 4.265 & 1.992 & $\mathrm{~S}$ \\
II Discussion & 64.55 & 76.26 & 11.71 & 2.22 & 52 & 5.275 & 2,007 & $\mathrm{~S}$ \\
\hline
\end{tabular}

\section{TABLE V}

\section{APPLICATION OF THE t-TEST TO INITIAL AND FINAL HEALTH ATTITUDE SCORES MADE BY THREE GROUPS}

\begin{tabular}{|c|c|c|c|c|c|c|c|c|}
\hline Group Approach & $\begin{array}{l}\text { Initial } \\
\text { Mean }\end{array}$ & $\begin{array}{l}\text { Final } \\
\text { Mean }\end{array}$ & $\begin{array}{l}\text { Differ- } \\
\text { ence }\end{array}$ & $\begin{array}{l}\text { Standard } \\
\text { Error of } \\
\text { Difference }\end{array}$ & df & $\begin{array}{c}\text { Obtained } \\
\mathrm{t}\end{array}$ & $\begin{array}{l}\text { t Value } \\
\text { of Sig- } \\
\text { nificance }\end{array}$ & Results \\
\hline Problems & 403.68 & 403.94 & .26 & 7.60 & 60 & .034 & 2.000 & NS \\
\hline Lecture & 399.23 & 403.92 & 4.69 & 4.81 & 76 & .975 & 1.992 & NS \\
\hline Discussion & 401.11 & 403.48 & 2.37 & 4.87 & 52 & 487 & 2.007 & NS \\
\hline
\end{tabular}


TABLE VI

\section{APPLICATION OF THE t-TEST TO INITIAL AND FINAL HEALTH INTEREST SCORES MADE BY THREE GROUPS}

\begin{tabular}{|c|c|c|c|c|c|c|c|c|}
\hline Group Approach & $\begin{array}{l}\text { Initial } \\
\text { Mean }\end{array}$ & $\begin{array}{l}\text { Final } \\
\text { Mean }\end{array}$ & $\begin{array}{l}\text { Differ- } \\
\text { ence }\end{array}$ & $\begin{array}{c}\text { standard } \\
\text { Error of } \\
\text { Difference }\end{array}$ & $\mathrm{df}$ & $\begin{array}{c}\text { Obtained } \\
\mathrm{t}\end{array}$ & $\begin{array}{l}\text { t Value } \\
\text { of Sig } \\
\text { nificance }\end{array}$ & Result \\
\hline I Problems & 84.94 & 89.74 & 4.80 & 4.28 & 60 & 1.143 & 2.000 & NS \\
\hline II Lecture & 82.13 & 91.50 & 9.37 & 3.26 & 74 & 2.874 & 1.992 & $\mathrm{~S}$ \\
\hline III Discussion & 78.41 & 88.23 & 9.82 & 4.00 & 42 & 2.455 & 2.017 & $\mathrm{~S}$ \\
\hline
\end{tabular}

The difference between initial and final mean health attitude scores under each approach was found to be nonsignificant (Table 5). The null hypotheses were held tenable. While a significant result in health knowledge was achieved under each approach, health attitudes were not significantly changed by any of the three approaches.

The difference between initial and final health interest scores was found to be significant under both the lecture and discussion approaches (Table 6). However, no significant difference was demonstrated under the problem solving approach. Hence the null hypothesis concerning the achievement in health interests under the problem solving approach was held tenable. The null hypotheses pertaining to achievement in health interests under the lecture and discussion approaches were rejected beyond the 45 percent level of confidence. A significant increase in health interests occurred under the lecture and discussion approaches while the problem solving approach failed to demonstrate a significant gain in health interests.

\section{DISCUSSION}

The results of the application of the $t$ tests to the initial and final scores for health knowledge and health attitudes (Tables 4 and 5) were consistent with the results of the application of the covariance technique (Tables 1 and 2). The results of the application of the test to the initial and final health interest scores shown in Table 6 were not in accordance with the results shown in Table 3 . The question thus presents itself; What are the causes which may contribute to the contradictory health interests. results?

The investigators are of the opinion that the following might be statistical factors in bringing about such results. As shown in Table 6, Group I had the highest mean value in initial interest in comparison with the other two groups. It might be concluded that the size of the largest initial mean cause difficulty in producing a significant $t$ value under this approach. The size of the standard error of statistics is considered as an index of reliability of the statistic being used. The larger the size of standard error, the less reliable is the statistic. Group I, under the problem solving approach, had the largest error value in comparison with the other two approaches. Therefore, the obtained difference between means under the problem solving approach might be considered less reliable as a statistic than the difference obtained under either the lecture or discussion approaches used with Group II and Group III. Hence less confidence was placed in the results pertaining to Group I than in the results obtained for Groups II and III. 


\section{CONCLUSIONS AND IMPLICATIONS}

Based on the above findings, it may be concluded that the problem solving, lecture, and discussion approaches are equally effective in achieving the desired outcomes of health instruction among undergraduate students. These results imply that the selection of an instructional approach should be made on the basis of criteria other than the generalized observations concerning the significance of the approach. Such criteria might include the degree to which "set" toward a certain teaching approach exists among the learners, an ability of the instructors to implement specific approaches, and the availability of time, materials, personnel, and facilities involved in various approaches.

\section{REFERENCES}

1. Beyer, Mary K. "College Health - Functional and Fun!" Journal of Health, Physical Education, and Recreation 27: 19-20; February 1956.

2. Bond, Betty Wells, "The Group Discussion-Decision Approach: An Appraisal of Its Use in Health Education.” Dissertation Abstracts XVI (1956).

3. Byrd, Oliver E. Byrd Health Attitude Scale. Sanford, California; Sanford University Press, 1940.

4. Clearly, Florence and others. "Project in Problem Solving." The Clearing House 23; 67- 770; October 1948.

5. Gross, Richard E., and Donald, Frederick J. "The Problem Solving Approach.” Phi Delta Kappan 39: 259-265; March 1958.

6. Hichman, Cleveland P. Health for College Students. Englewood Cliffs, N.J.: Prentice Hall, Inc., 1958.

7. Jensen, Arthur M. “An Experimental Evaluation of Two Different Programs of Teaching Health in the Sixth Grade and the Administrative Implications Involved." Journal of Experimental Education 27:203-210; March 1959.

8. Knight, S.S., and Mickelson, J.M. "Problem vs Subject." The clearing House 24: 3-7; September 1949.

9. Kilander, H. Frederick. Kilander Knowledge Test (College). East Orange, J>J $>$; the author, 33 Colonial Terrace: 1958

10. Malfetti, James L. "Let's Put Life Into College Health Education." Journal of Health, Physical Education, and Recreation 27: 35-56;January 1956.

11. Olson, Kenneth V. "An Experimental Evaluation of A Student-Centered Method and A Teacher-Centered Method of Biological Science Instruction for General Education of College Students.” Journal of Experimental Education 27: 225-58; March 1958.

12 Russell, Robert D. "The Essentials of Good College Teaching." Journal of Experimental Education 30: 26,27,36; October 1959.

13. Stovall, Thomas F. "Lecture vs. Discussion." Phi Delta Kappan 39; 225-58; March 1959

14. Whitely, William E.R. A Survey of Health Interests of Selected College Students. Doctoral Dissertation, Bloomington : Indiana-University, School of Health, Physical Education and Recreation, 1957. 